\title{
DP による系統信号の遅れ最小化制御と通過帯幅最大化制御 \\ DELAY-MINIMIZING CONTROL AND BANDWIDTH-MAXIMIZING CONTROL OF COORDINATED TRAFFIC SIGNALS BY DYNAMIC PROGRAMMING
}

\author{
久井 守* \\ By Mamoru HISAI
}

\begin{abstract}
In this paper, a method of calculation is proposed to determine the optimum offsets of coordinated traffic signals so as to minimize the total traffic delay on a street. The optimization technique employed is dynamic programming. The platoon is supposed to be represented by a single rectangle and to be dispersed as it travels. The method is programmed for the numerical computation. The optimum offsets can be obtained for a streets under the arbitrary road and traffic conditions. Some examples are worked out.

Furthermore, it is shown that, by using the same method as mentioned above, bandwidth-maximizing offsets can be obtained under the condition of no dispersion of platoon and no traffic delay, and that the bandwidth is equal to maximum platoon length.
\end{abstract}

\section{1.はしがき}

本研究は 1 本の路線上の交通信号を対象とした, いわ ゆる路線系統制御について遅れ最小化を基準としたオフ セット最適化を行い, あわせて遅れ最小化の観点から通 過帯幅最大化オフセットについて検討したものである. すなわち, 各信号交差点で生じる交通流の総遅れ時間を 最小にするオフセットをDP モデルによって求め，ま た同じ DP モデルを用いて，通過帯幅最大化基準によ る最適オフセットを求めている.これによって 1 つの $\mathrm{DP}$ モデルで, 計算条件を変更すれば, 遅れ最小化およ び通過帯幅最大化の両基準によるオフセット最適化のい ずれも実行可能であることを示す。

通過帯幅最大化基準 ${ }^{1) ~ 3)}$ は, 従来から広く用いられて きた基準であって，この通過帯法は必ずしも遅れ最小を 保証するものではないが, 交通量が比較的少ない場合は 遅れ最小化の観点からみてもかなり優れた方法であると 考えられる. 本研究は通過带法の評価や制御理論として の位置づけなどの問題点を明らかにしたものではない が, 今後これらの問題点を明らかにしていくうえで重要 なステップにしたいと考えている.

ところで通過帯法は, 交通流の 2 方向性と上流信号の

* 正会員 工博 山口大学講師 工学部土木工学科 （テ755 宇部市常盤台 2557）
影響を考慮した方法, すなわち, 信号相互間の影響を総 合的に考慮した方法である。遅れ最小化基準でこのよう に信号相互の影響を考慮したオフセットの最適化はきわ めて困難であるが，一連の仮定にたてば，DP の手法に よって最適化することが可能であり，すでに著者らは $\mathrm{DP}$ モデルによる基本的な方法を提案している4 . 以下, その DP モデルを従来の DP モデルとよぶこととする. 本研究では, この従来の DP モデルに, いくつかの重 要な改良を加えて, 遅れ最小化基準による最適オフセッ トを求める. さらにこの DP モデルによって通過帯幅 最大化基準による最適オフセットを求め, 通過帯幅最大 化オフセットは一定の計算条件下では遅れ最小化オフ セットの 1 つの特別な解として得られることを示す.

なお, 本研究に関連する研究として, 遅れ時間は考慮 していないが DP を用いて通過帯幅最大化の手法を示

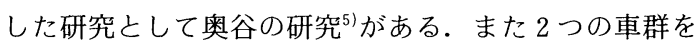
考慮した DP モデル ${ }^{6)}$ や街路網のループ閉合条件を DP の手法で処理した研究7)がある.

\section{2. 交通流の仮定と遅れ時間}

\section{（1）単一矩形波と拡散の仮定}

信号交差点では交通流は車群を形成する：この車群を ここでは図一1に示すように単一の矩形波で仮定する. $L$ は車群長 $(\mathrm{s}), a$ は車群内のフローレート（台/s）で 


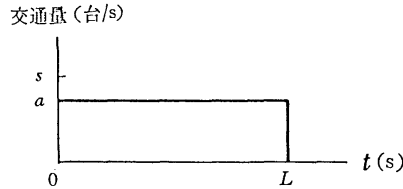

図一1 車群の仮定

ある. 1 周期当たりの交通量（台/cycle）は

$Q=a L$

となる．車群は走行中に拡散すると考え，交差点への到 着車群長を

$$
L=c D+L_{0}
$$

と仮定する。ここに $L_{0}$ は隣接上流交差点の発進車群長 $(\mathrm{s}), D$ は交差点間隔 $(\mathrm{m}), c$ は車群の広がりを表わ す広がり係数である.

\section{（2）車群パタンの変換過程の仮定}

信号交差点で車群はパタンの変換を受けるが, その変 換ルールを図一2のように仮定する．パタン変換の前後 とも，車群はすべて単一の矩形波と仮定する．図の縦軸

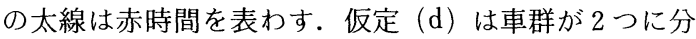
割される場合であるが,この場合も単一の矩形波とする. 仮定（c）は車群が赤信号にかからない場合である．従 来の DP モデルでは, 関数方程式の次元数を増やさな いため図一3のように車群を車群長のみで表現する必要 上，車群長を青開始時点からの長さにしていたのを，本 研究ではこれを図一2(c) のように改良し, 車群を車群 長および車群位置を表わす変数で表現するようにしたも のである.この改良が本研究における重要な改良の 1 つ である，以下では，従来の DP モデルを無停止通過車 群を考慮しない場合のモデル, 改良後の DP モデルを 無停止通過車群を考慮した場合のモデルとよぶこととす

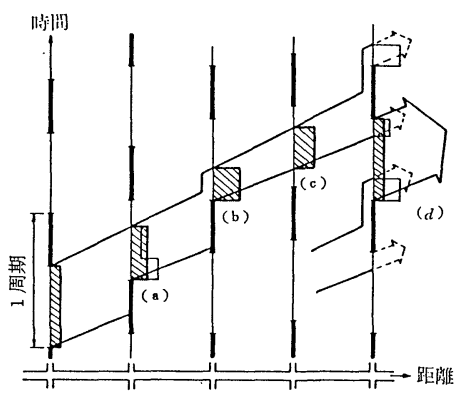

図一2 車群パタンの变換ルール

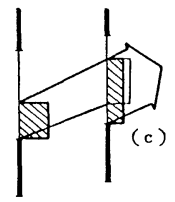

図一3無停止通過車群を考虑しない場合の変換ルール
る。

\section{（3）遅れ時間}

車群パタンを単一の矩形波で表わしたときの遅れ時間 $w$ は到着車群長と到着時点に応じて次の 6 つの式で表 わされる8).

$$
\begin{aligned}
& w_{1}=0 \\
& w_{2}=\frac{a s}{2(s-a)}(\xi+\lambda-g)^{2} \\
& w_{3}=\frac{a s}{2(s-a)} r^{2} \\
& w_{4}=q(\xi-g)+\frac{q}{2 s}(s \lambda+q) \\
& w_{5}=\frac{a}{2 s}\left\{-(s-a) \xi^{2}+2(s g-a) \xi+s r-s g+a\right\} \\
& w_{6}=(a-q)(1-\xi)+\frac{a s}{2(s-a)}(\lambda-g)^{2}
\end{aligned}
$$

ここに $s$ は飽和流量 (台/s), $\xi$ は車群後端が交差点に 到着した時点から青信号終了時点までの時間， $g$ は青時 間, $r$ は赤時間, $\lambda$ は車群長 $(\lambda=L / T), q$ は交通量 $(q$ $=Q / T), T$ は信号周期である. $\xi, g, r$ などの時間量 は周期に対する比の値である. 遅れ時間 $w$ の単位は台・ $\mathrm{s} / \mathrm{s}$ を周期で規準化したものである.したがって台・s/s 単位の遅れ時間 $W$ は, $W=w T$ で求められる. 以上は $a<s$ で, かつ $a T \leqq s G$ の場合の遅れ時間であるが, この場合の遅れ時間を $\xi$ の関数として表わしたものの 一例を図一 4 に示す。

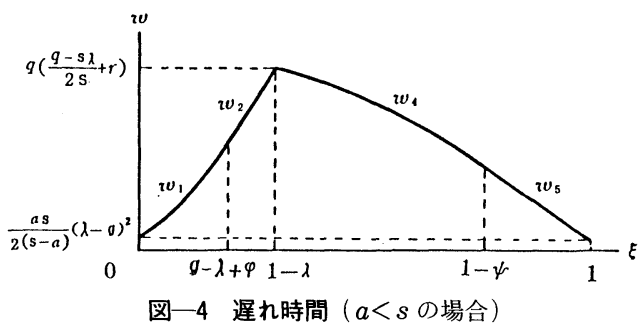

一方, 車群の拡散がなく, 車群内のフローレートが飽 和流量に等しく $(a=s)$, かつ $\lambda \leqq g$ である場合の遅れ 時間を示すと図一5のようになる．この場合

$$
\begin{aligned}
& 0 \leqq \xi \leqq g-\lambda \text { のとき } \\
& w=0 \\
& g-\lambda \leqq \xi \leqq 1-\lambda \text { のとき } \\
& w=s \lambda(\xi+\lambda-g) \text {. } \\
& 1-\lambda \leqq \xi \leqq 1 \text { のとき } \\
& w=s r(1-\xi)
\end{aligned}
$$

である. 本研究では車群の拡散がなく $(c=0)$, かつ $a$ $=s$ である場合についても扱うことができるように，遅 れ時間関数として新しく式 $(9)$ ( 11$)$ を導入したが, 


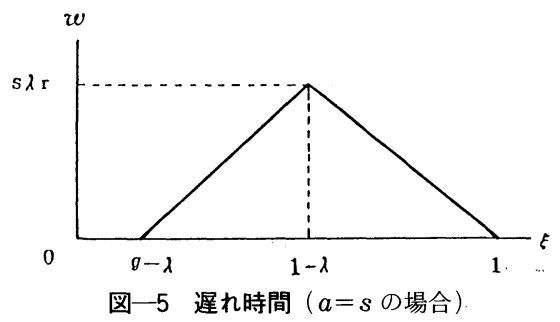

これも従来の DP モデルに対する改良点の 1 つである.

\section{（4）境界交差点からの流入パタン}

系統化の対象は, 距離の長い信号区間または車群の存 在が認められない信号区間によって区切られた路線内の 信号とするべきである．そのようにした場合，対象路線 の両端交差点に到着する交通パタンは一様流またはそれ に近いものになる。一様到着の場合の発進交通パタンは 図一6 破線で示すように 2 段の階段波になる. 図の横 軸の太線は赤時間を示す. 本研究では単一矩形波の仮定 を設けているので，この流入パタンを図一6の実線で示 すように次の 3 通りに仮定し, 計算時にいずれか 1 つを 指定できるようにしている.

流入パタン $1: \lambda=g, \alpha=q / \lambda$

流入パタン $2: \lambda=2 \lambda_{g}, a=q / 2 \lambda_{g}$

流入パタン $3: \lambda=q / s, a=s$
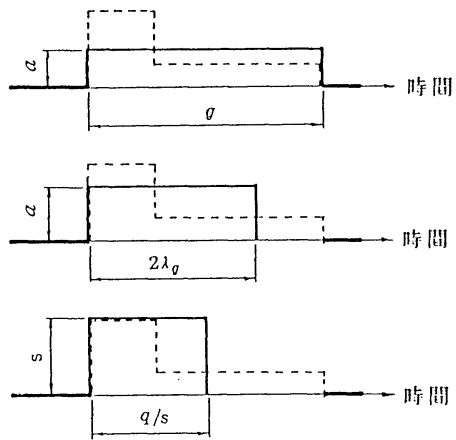

図一 流入パタンの仮定

流入パタン 1 は従来の DP モデルで用いた仮定である が交通量の少ないときは, 実際の車群パタンとかなりか け離れたものになる。したがって本研究では，流入車群 長を, 青開始時点から破線で示した 2 段階波の図心まで の長さ $\lambda_{g}$ の 2 倍にとるという仮定を導入した.これが 流入パタン 2 である.もう 1 つ考えられる仮定として， 飽和発進の仮定がある。これが流入パタン 3 である. 本 研究では流入パタンをこのように 3 通りに仮定したがこ れも従来の DP モデルに対する改良点の 1 つである.

（5）その他の仮定

交差点での右左折はないとし，信号区間途中での交通 の流出入はないものとする，車群の速度は上り，下りの
両方向で異なり，信号区間ごとにも異なると考える．ま た現示率は交差点ごとに異なると考える.

\section{DP による定式化と計算法}

（1）定 式 化

最適化の対象路線を図一7のように表わす，最適化の 目的関数 $J$ を対象路線全区間の総遅れ時間とすると,

$$
J=\sum_{k=1}^{N}\left\{w_{k}\left(\lambda_{k}, x_{k}, \xi_{k}\right)+w_{k}^{\prime}\left(\lambda_{k}^{\prime}, x_{k}^{\prime}, \xi_{k}^{\prime}\right)\right\}
$$

となる.この $J$ を最小にする最適決定 $\xi_{k}^{*}(k=1,2, \cdots$, $N)$ を探索することが目的である。ここに $w_{k}$ は図一8 に示すように第 $k$ 区間上り方向車群が第 $k$ 交差点でこ うむる遅れ時間であり，これは $\lambda_{k}, x_{k}$ および $\xi_{k}$ の関数 である。 $\lambda_{k}$ は発進車群長, $x_{k}$ は発進車群位置， $\xi_{k}$ は到 着車群位置を表わす．また， $w_{k}^{\prime}$ は第 $k$ 区間下り方向車 群が第 $(k-1)$ 交差点でこうむる遅れ時間であり，こ れは $\lambda_{k}^{\prime}, x_{k}^{\prime} お よ ひ ゙ ~ \xi_{k}^{\prime}$ の関数である.

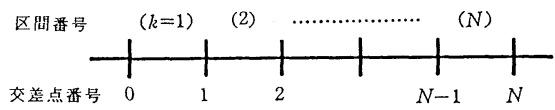

図一7 DPの対象路線

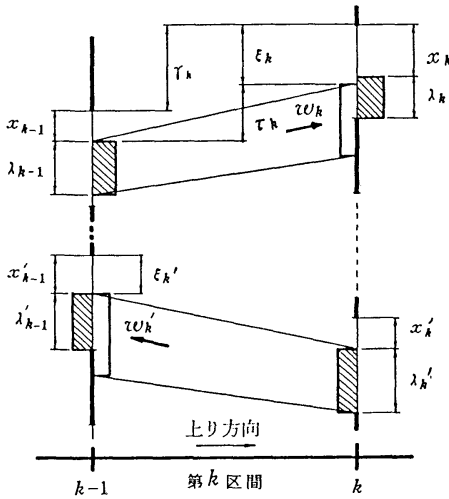

図一8 第 $k$ 区間の車群と遅れ時間

上り方向の車群について， $\lambda_{k}$ と $x_{k}$ はいずれも $\lambda_{k-1}$ お よび $\xi_{k}$ の関数であり, 図一2の車群変換ルールに対応 して次のように表わすことができる.

(a) $0 \leqq \xi_{k}<g_{k}-q / s$ かつ

$$
\left.\begin{array}{c}
g_{k} \leqq \xi_{k}+\left(c D_{k}+\lambda_{k-1}\right) \leqq 1 \text { のとき } \\
\lambda_{k}=g_{k}-\xi_{k} \\
x_{k}=\xi_{k}
\end{array}\right\}
$$

(b) $\xi_{k} \geqq g_{k}-q / s$ かつ

$$
\xi_{k}+\left(c D_{k}+\lambda_{k-1}\right) \leqq 1 \text { のとき }
$$

$$
\left.\begin{array}{l}
\lambda_{k}=q / s \\
x_{k}=g_{k}-q / s
\end{array}\right\}
$$

(c) $0 \leqq \xi_{k} \leqq g_{k}-q / s$ かつ 


$$
\left.\begin{array}{c}
\xi_{k}+\left(c D_{k}+\lambda_{k-1}\right)<g_{k} \text { のとき } \\
\lambda_{k}=c D_{k}+\lambda_{k-1} \\
x_{k}=\xi_{k}
\end{array}\right\}
$$

(d) $\xi_{k}<1$ かつ

$$
\left.\begin{array}{c}
\xi_{k}+\left(c D_{k}+\lambda_{k-1}\right)>1 \text { のとき } \\
\lambda_{k}=g_{k} \\
x_{k}=0
\end{array}\right\}
$$

ここに $g_{k}$ は第 $k$ 交差点の青時間， $D_{k}$ は第 $k$ 区間の区 間距離 $(\mathrm{m})$ である. $\left(c D_{k}+\lambda_{k-1}\right)$ は第 $k$ 交差点への到 着車群長であり，これが 1 より大きい場合は 1 に置き換 えるものとする，下り方向についても同様であり， $\lambda_{k-1}^{\prime}$ と $x_{k-1}^{\prime}$ はいずれも $\lambda_{k}^{\prime} お よ ひ ゙ \xi_{k}^{\prime}$ の関数である.

式(12)を DP の関数方程式で表わすと,

$$
\begin{gathered}
f_{k}\left(\lambda_{k}, x_{k}, \lambda_{k}^{\prime}, x_{k}^{\prime}\right)=\min _{\xi k}\left\{w_{k}\left(\lambda_{k}, x_{k}, \xi_{k}\right)+w_{k}^{\prime}\left(\lambda_{k}^{\prime}, x_{k}^{\prime}, \xi_{k}^{\prime}\right)\right. \\
\left.+f_{k-1}\left(\lambda_{k-1}, x_{k-1}, \lambda_{k-1}^{\prime}, x_{k-1}^{\prime}\right)\right\} \cdots \cdots \cdots \cdots \cdots \cdots \cdots \cdots(13 \\
(k=1,2, \cdots, N)
\end{gathered}
$$

となる.ここに $f_{k}\left(\lambda_{k}, x_{k}, \lambda_{k}^{\prime}, x_{k}^{\prime}\right)$ は第 1 区間一第 $k$ 区 間までの最適政策によって得られる最小遅れ時間であ り,これは 4 つの変数 $\lambda_{k}, x_{k}, \lambda_{k}^{\prime}, x_{k}^{\prime}$ の関数であると考 える， $f_{k}$ の意味を図に示すと図一9のようになる．また

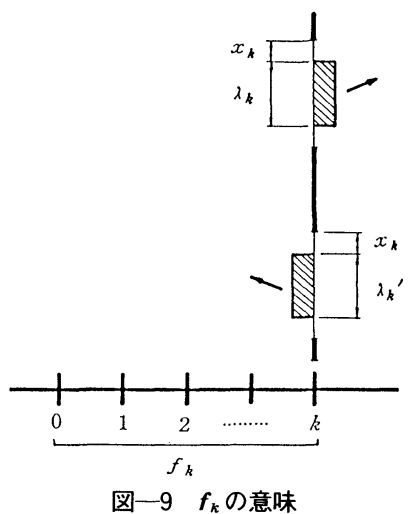

$f_{0}=0$ とする. 式 (13) における $\xi_{k}$ と $\xi_{k}^{\prime}$ の間には

$$
\xi_{k}^{\prime}=1-\tau_{k}-\tau_{k}^{\prime}+x_{k}^{\prime}+x_{k-1}-\xi_{k}
$$

なる関係があるので，式（13）は $\xi_{k}$ に関して最小化す ればよい. 式 (14) において $\tau_{k}$ および $\tau_{k}^{\prime}$ は次式に示す ように信号区間距離 $D_{k}$ の走行所要時間を周期で規準化 したものである.

$$
\begin{aligned}
& \tau_{k}=D_{k} / T v_{k} \\
& \tau_{k}^{\prime}=D_{k} / T v_{k}^{\prime}
\end{aligned}
$$

ここに $v_{k}, v_{k}^{\prime}$ はそれぞれ上り方向および下り方向の走 行速度 $(\mathrm{m} / \mathrm{s})$ である. 最適決定 $\xi_{k}^{*}$ が求められると最 適オフセット $\gamma_{k}^{*}$ は次式で求めることができる.

$$
\gamma_{k}^{*}=\xi_{k}^{*}+\tau_{k}-x_{k-1} \quad(\bmod 1) \cdots
$$

ただし $\gamma_{k}^{*}$ は青時間終了時点の時間差である.

なお本研究の無停止通過車群を考慮した DP モデル
では関数方程式は $f_{k}\left(\lambda_{k}, x_{k}, \lambda_{k}^{\prime}, x_{k}^{\prime}\right)$ のように 4 変数の 関数となるが, 無停止通過車群を考慮しない従来の DP モデルでは，車群パタンの変換過程を図一3のように簡 略化しているので車群の位置を表わす変数 $x_{k}, x_{k}^{\prime}$ は必 要ではなく, 関数方程式は $f_{k}\left(\lambda_{k}, \lambda_{k}^{\prime}\right)$ のように 2 変数 のみの関数となっている.この分だけ本研究では計算時 間が長くなることになる.

\section{（2）計算方法}

計算は格子点探索法で行う。まず

$$
f_{0}\left(\lambda_{0}, x_{0}, \lambda_{0}^{\prime}, x_{0}^{\prime}\right)=0
$$

とおくが, 4 つの変数 $\lambda_{0}, \lambda_{0}^{\prime}, x_{0}, x_{0}^{\prime}$ は

$$
\begin{aligned}
& q / s \leqq \lambda_{0} \leqq g_{0} \\
& q^{\prime} / s \leqq \lambda_{0}^{\prime} \leqq g_{0} \\
& 0 \leqq x_{0} \leqq g_{0}-\lambda_{0} \\
& 0 \leqq x_{0}^{\prime} \leqq g_{0}-\lambda_{0}^{\prime}
\end{aligned}
$$

の範囲を $\lambda_{0}, \lambda_{0}^{\prime}$ は $\Delta \lambda$ 間隔, $x_{0}, x_{0}^{\prime}$ は $\Delta x$ 間隔の離散量 で与える (図一10).

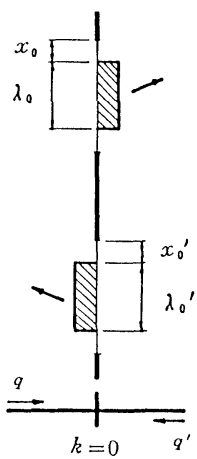

\section{図一10 第0 交差点の車群の与え方}

一般に第 $k$ 区間の計算では, 4 つの変数 $\lambda_{k}, \lambda_{k}^{\prime}, x_{k}$, $x_{k}^{\prime}$ は

$$
\begin{aligned}
& q / s \leqq \lambda_{k} \leqq g_{k} \\
& q^{\prime} / s \leqq \lambda_{k}^{\prime} \leqq g_{k} \\
& 0 \leqq x_{k} \leqq g_{k}-\lambda_{k} \\
& 0 \leqq x_{k}^{\prime} \leqq g_{k}-\lambda_{k}^{\prime}
\end{aligned}
$$

の範囲を $\lambda_{k}, \lambda_{k}^{\prime}$ は $\Delta \lambda$ 間隔, $x_{k}, x_{k}^{\prime}$ は $\Delta x$ 間隔の離散量 で与える. $q$ は上り方向交通量 (台/s)， $q^{\prime}$ は下り方向 交通量（台/s）である. $\lambda_{k}, \lambda_{k}^{\prime}, x_{k}, x_{k}^{\prime}$ のあらゆる組合 せについて $f_{k}$ の值を式 (13) によって求める. $f_{k}$ は $\xi_{k}$ について最小化を行うが， $\xi_{k}$ は $\Delta \xi$ 間隔の離散量として 最適化を行う. その場合, $\xi_{k}$ は車群パタン $\left(\lambda_{k-1}, x_{k-1}\right)$ と $\left(\lambda_{k}, x_{k}\right)$ は車群パタンの変換ルールを満足するよう に設定する．可能な $\xi_{k}$ が一定の範囲を有する場合はそ の中から式 (13) の $\left\{w_{k}+w_{k}^{\prime}+f_{k-1}\right\}$ を最小にするように $\xi_{k}$ を决定する.ただし与えられた $\xi_{k}$ に対して，下り方 向の車群パタン $\left(\lambda_{k}^{\prime}, x_{k}^{\prime}\right)$ と $\left(\lambda_{k-1}^{\prime}, x_{k-1}^{\prime}\right)$ が車群パタン 
の変換ルールを満足しない場合, その $\xi_{k}$ は最適オフセッ トの候補から除外することとする.

\section{(3) 計 算 例}

計算例として図一-11に示す 8 信号からなる路線につ

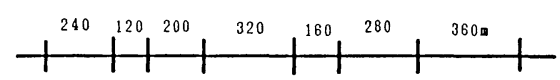

図一11計算例に用いた路線

いて計算を行った。計算条件としては

$\Delta \lambda=0.1, \Delta x=0.1, \Delta \xi=0.025, s=1$ 台 $/ \mathrm{s}$ $c=0.017, v=v^{\prime}=12 \mathrm{~m} / \mathrm{s}, \quad g=0.6$

とし，交通条件，信号条件としては，

(1) $q=q^{\prime}=0.3$ 台 $/ \mathrm{s}$

$T=60,70,80,90,100 \mathrm{~s}$

(2) $T=60 \mathrm{~s}$

$q=q^{\prime}=0.1,0.2,0.3,0.4,0.5$ 台/s

(3) $T=60 \mathrm{~s}, q=0.3$ 台 $/ \mathrm{s}$

$q^{\prime}=0.1,0.2,0.3,0.4,0.5$ 台/s

の 3 通りを用いた. 無停止通過車群を考慮しない DP
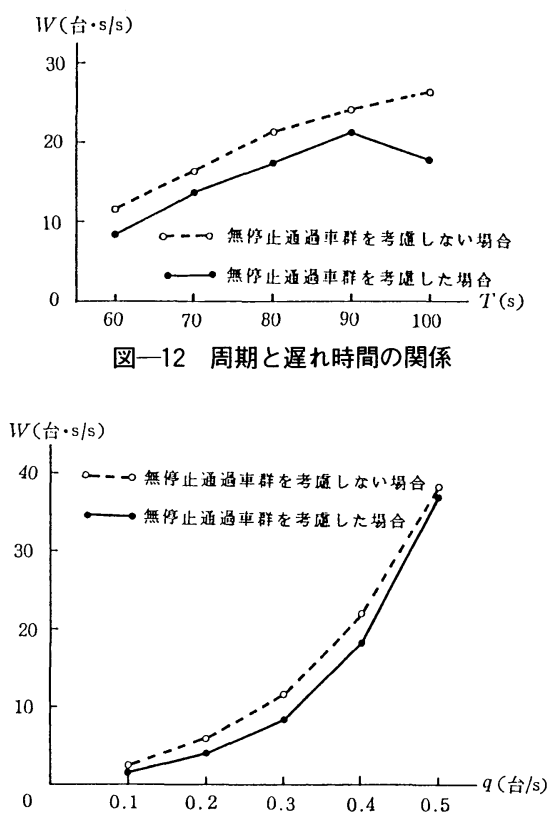

図一13 交通量と遅れ時間の関係

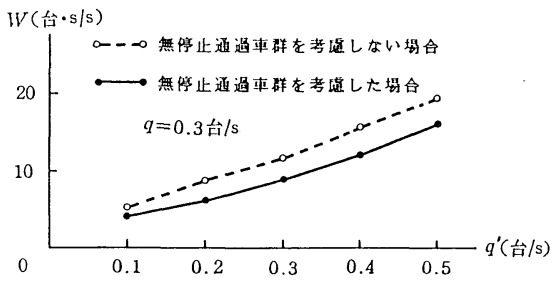

図一14 下り方向交通量と遅れ時間の関係
モデルと, 無停止通過車群を考慮した DP モデルの両 者によって計算を行い，遅れ時間を比較したのが，図一 12〜図-14である. 図一12 は周期と遅れ時間の関係を 示し，図一13 は交通量と遅れ時間の関係を示し，また 図一14 は上り交通量を一定に保ち, 下り交通量を変化

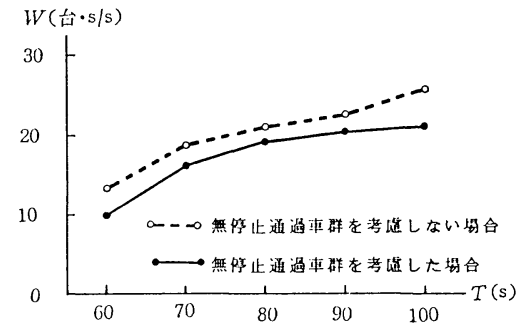

図一15 周期と遅れ時間の関係（流入パタン 2 の場合）

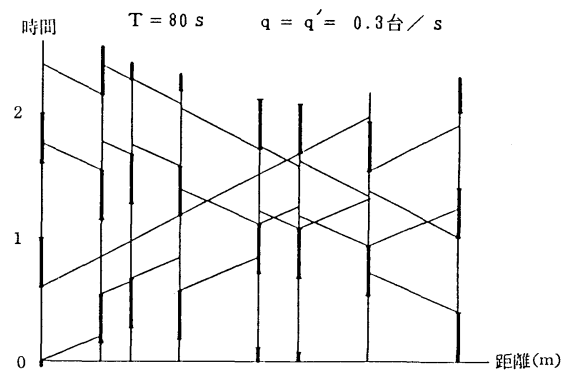

（a）無富止通過車群を考虑しない埸合

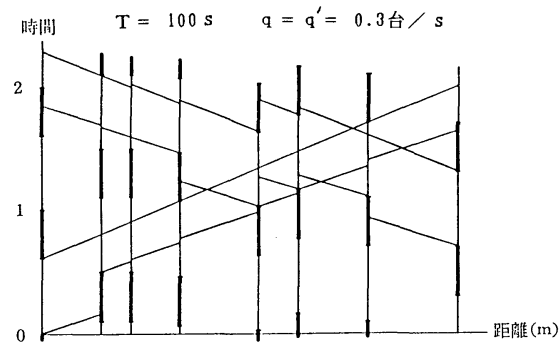

（b）無停止通過車群を考虑した場合

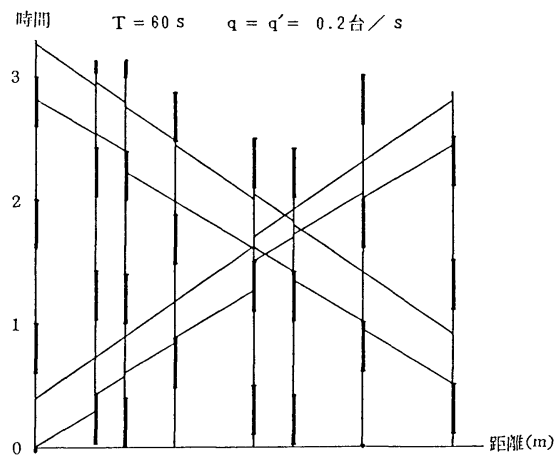

（c）無停止通通車群を考虐した場合

（流入バタン 2 の場合）

図一16 最適オフセットと交通流パタン 
させたときの遅れ時間を示したものである.いずれも無 停止通過車群を考慮した DP モデルによる方が遅れ時 間が小さくなっていることがわかる.これらの計算結果 は，境界条件として流入パタン 1 , すなわち上り方向交 通については

$$
\lambda_{0}=g_{0}, x_{0}=0
$$

とし,下り方向については

$$
\lambda_{N}^{\prime}=g_{N}, x_{N}^{\prime}=0
$$

として得たものである.

また境界条件として，流入パタン 2 を用いた計算も 行った. その結果, 全般に若干遅れ時間が増加するが, ほぼ図一13〜図一15の傾向と同様の傾向が得られた. ただ遅れ時間と周期の関係が多少異なるのでそれを図一 15 に示す.

次に代表的なオフセットパタンと交通流パタンを時間 距離図上に示したのが図一16である. 図 (a) は無停止 通過車群を考慮しない DP モデルによる計算結果であ り $T=80 \mathrm{~s}, q=q^{\prime}=0.3$ 台/s の場合である. この場合 ではたとえば，第 4 番目交差点で上り方向車群の車群長 が不連続に大きくなるという結果となっている. 図 (b) は無停止通過車群を考慮した DP モデルによる計算結 果であり, $T=100 \mathrm{~s}, q=q^{\prime}=0.3$ 台/s の場合である.

図 (c) は境界条件, すなわち両端交差点からの流入車 群パタンとして流入パタン 2 を用い, $T=60 \mathrm{~s}, q=q^{\prime}$ $=0.2$ 台 $/ \mathrm{s}$ とした場合の計算結果である.この例では, 交通量が少ないこともあって，車群長を短くして，でき るだけ赤信号にかからないように各交差点を通過させる という結果になっている.

\section{4. 通過帯幅最大化オフセット}

以上において，遅れ最小化を基準とした場合のオフ セット最適化を DP の手法によって定式化し, 計算法 を示し, いくつかの計算例について計算を行った. 次に この DP モデルを用いて, 通過帯幅を最大化するオフ セットを求める方法を示し，いくつかの計算例について 計算を行う.

\section{（1）計算方法}

基本的には無停止通過車群を考慮した DP モデルを そのまま用いるのであるが，若干モデルの修正を行う.

修正の第 1 点は信号交差点における車群パタンの変換 過程において，一定の変換誤差を許容しているために下 り交通については交差点への到着車群と発進車群の後端 が最大 $1 / 2 \Delta x$ だけ食い違う場合があった点を解消する ことである.そのために, DP 計算の第 $k$ 段階（第 $k$ 区間）の計算の例についていえば，隣接上流側信号の発 進車群の $\lambda_{k}^{\prime}, x_{k}^{\prime}$ のいずれか, またはその両方を微調整 して下り側信号の発進車群に合わせるように修正する.
修正の第 2 点は境界条件の取扱いの変更である．すな わち, DP モデルでは両端交差点からの流入車群につい ては流入パタン 1 3を仮定しているが，ここでは流入 車群長を上り交通については

$$
\lambda_{0}=q / s, x_{0}=0 \sim\left(g_{0}-q / s\right)
$$

とし, 下り交通については

$$
\lambda_{N}^{\prime}=q^{\prime} / s, \quad x_{N}^{\prime}=0 \sim\left(g_{N}-q^{\prime} / s\right)
$$

とする.すなわち, 車群内のフローレートは流入パタン 3 と同じく飽和流量に等しくするが車群の位置 $x_{0}, x_{N}^{\prime}$ は 1 つに固定せず， $x_{0}$ は $\Delta x_{0}$ きざみ， $x_{N}^{\prime}$ は $\Delta x$ きざみ に変化させる.きざみ幅 $\Delta x_{0}$ の大きさは得られる最大 通過帯幅に影響するので，演算速度と記憶容量の許す範 囲でできるだけ小さくする.

修正の第 3 点は入力デー夕の変更である．まず車群の 拡散はないとして, 広がり係数は

$$
c=0
$$

とおく.また便宜的に飽和流量を

$$
s=1 \text { 台/s }
$$

と与える. そうすることにより

\section{上り通過帯幅は $q$}

下り通過带幅は $q^{\prime}$ で与えられることになる。

通過帯幅最大化オフセットはトライアルに求める。す なわち, $q$ および $q^{\prime}$ を与えて DP 計算を行い, 総遅れ が 0 となる範囲でできるだけ大きい $q$ および $q^{\prime}$ が得ら れるまで DP 計算を繰り返すことによって求める. 実 際には $q$ を 0.1 から 0.1 きざみで増加させていき, 総 遅れが 0 から正に変化した区間について 2 分法によって $q$ の精度を高めていくという計算が合理的であろう.

\section{(2) 計 算 例}

図一11に示す路線を例として計算を行う。まず比較

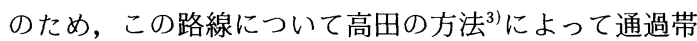
法の平等オフセットを求めたのが図一17である. $T=$ $80 \mathrm{~s}, v=v^{\prime}=12 \mathrm{~m} / \mathrm{s}, g=0.6$ なる条件で求めたもので あるが，この場合は通過帯幅 $B=0.267$ (対周期比）と なっている.

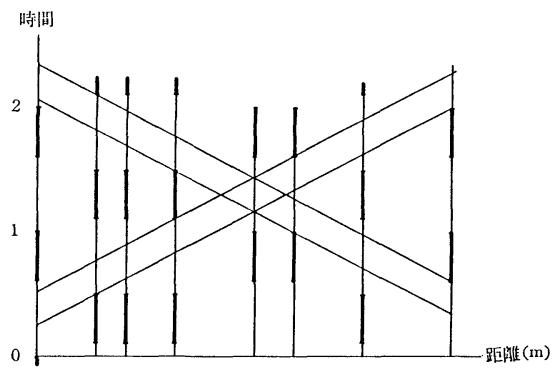

図一17 通過帯法およびDPモデルで求めた平等オフセット (速度が等しい場合) 
次に DP モデルによって通過帯幅最大化オフセット を求める。計算条件は

$\Delta \lambda=0.1, \Delta x=0.1, \Delta x_{0}=0.015$,

$\Delta \xi=0.025, s=1$ 台 $/ \mathrm{s}, c=0, T=80 \mathrm{~s}$

とし，特に指定しない場合は

$v=v^{\prime}=12 \mathrm{~m} / \mathrm{s}, \quad g_{i}=0.6 \quad(i=0,1,2, \cdots, 7)$

とする. 通過帯幅は 0.005 の精度まで求めた.

a ）上下両方向の速度が等しい場合の平等オフセット

上下両方向の速度が等しい場合の平等オフセットを DP モデルによって求めたところ図一17とほぼ同じ結 果が得られた。ただし高田の方法によって求めた通過帯 幅が $B=0.267$ であるのに対してこの場合の通過帯幅は $B=0.260$ にとどまっているが, これは, 車群長 $\lambda$, 車 群位置 $x$, およびオフセット $\xi$ を離散量として扱って いることに起因している，また，この結果は遅れ時間に 影響しない範囲でオフセットを同時式あるいは交互式に なるように微調整するルーチンを付加したアルゴリズム による結果である. 微調整ルーチンをスキップしオフ セットの移動を行わない場合の計算結果は図一18のよ うに得られている.

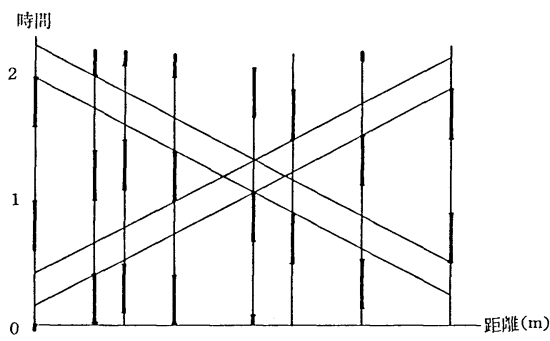

図一18 平等オフセット（オフセットの移動を行わない場合）

b ）不平等オフセット

上り通過帯幅と下り通過帯幅が $2: 1$ であるという条 件を与えて求めたオフセットパタンは図一19のとおり である. 上り通過带幅は $B=0.350$, 下り通過帯幅は $B^{\prime}$ $=0.175$ となっている. この結果を図一17に比較すると 通過帯幅を規定するクリティカルな信号のオフセットが 移動していることがわかる.

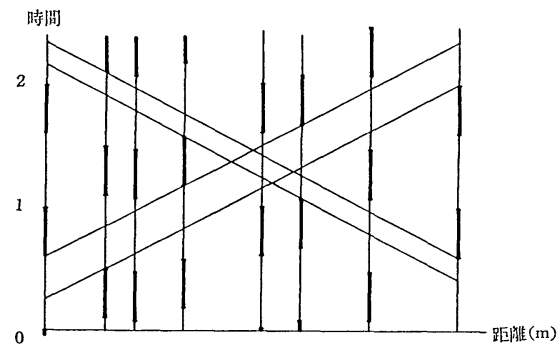

図一19 不平等オフセット $\left(q: q^{\prime}=2: 1\right.$ の場合 $)$
このような計算以外に，たとえば，上り通過帯幅を指 定し, その条件下で下り通過帯幅を最大にするような才 フセットパタンについても求めることができる.

c ）上りと下りの速度が異なる場合

上り方向の速度を $v=12 \mathrm{~m} / \mathrm{s}$ とし, 下り方向の速度 を $v^{\prime}=10 \mathrm{~m} / \mathrm{s}$ とした場合の平等オフセットを求めると 図一20のようになる。この場合の通過帯幅は $B=0.230$ となっている.

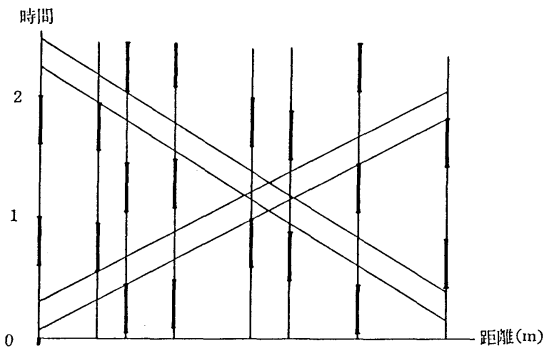

図一20 上りと下りの速度が異なる場合の平等オフセット

d）区間ごとに速度が異なる場合

第 3 区間と第 5 区間の速度を上下両方向とも $10 \mathrm{~m} / \mathrm{s}$ とし，それ以外は $12 \mathrm{~m} / \mathrm{s}$ とした場合の平等オフセット を求めると図一21 のようになり，この場合の通過帯幅 は $B=0.210$ となっている.

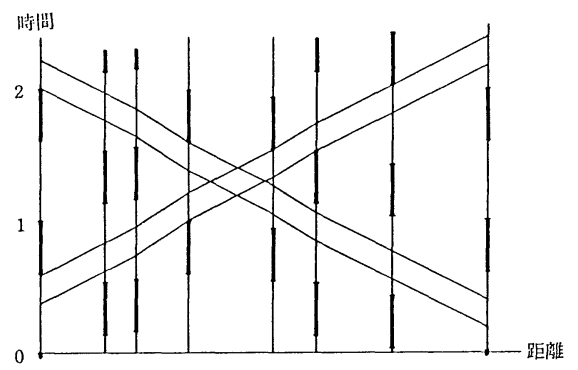

図一21 区間ごとに速度が異なる場合の平等オフセット

e ）一般的な条件下の平等オフセット

速度が上下両方向で異なり，また区間ごとにも異なる という条件のほか，スプリットも信号ごとに異なるとい う一般的な条件下で平等オフセットを求めたのが図一22 である．通過帯幅は $B=0.255$ となっている.

f ) 図一11に示す路線を対象として 50〜 $120 \mathrm{~s}$ の各 周期に対する平等オフセットを通過帯法とDP モデル の両者で計算を行った. その結果，通過帯法によって求 めた平等オフセットと DP モデルによって求めた平等 オフセットは同じものが得られた.ただし表一1に示す ように $T=70 \mathrm{~s}$ およ゙ $T=120 \mathrm{~s}$ において DP モデルで 求めた通過帯幅が，通過帯法で求めた通過帯幅よりかな り小さくなっている. これは $\Delta \lambda=0.1, \Delta x=0.1$ とい 


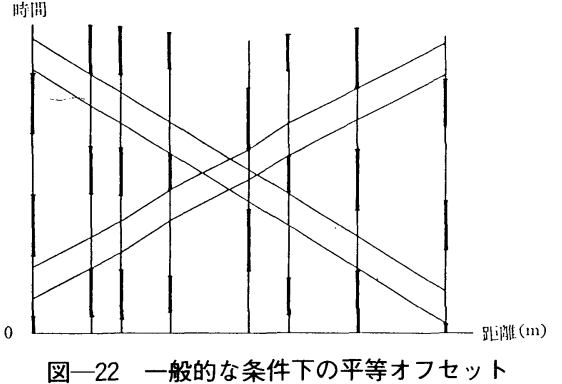

\begin{tabular}{|c|c|c|}
\hline \multirow{2}{*}{$\begin{array}{l}\text { 周期 } \\
\mathrm{T}(\mathrm{s})\end{array}$} & \multicolumn{2}{|c|}{ 通通考帽 B } \\
\hline & 通通背法 & D P モデル \\
\hline $50 \mathrm{~s}$ & 0.200 & 0.195 \\
\hline $60 s$ & 0.322 & 0.310 \\
\hline $70 s$ & 0.243 & 0.215 \\
\hline $80 s$ & 0.267 & 0.260 \\
\hline $90 \mathrm{~s}$ & 0.267 & 0.250 \\
\hline $100 s$ & 0.200 & 0.195 \\
\hline $110 \mathrm{~s}$ & 0.287 & 0.260 \\
\hline $120 s$ & 0.239 & 0.195 \\
\hline
\end{tabular}

うようにステップ幅を大きくしたことによる影響であ り，DP モデルの基本的考え方に起因するものではない.

以上により，通過帯幅最大化オフセットは DP の遅 れ最小化モデルにおいて，両端交差点からの流入車群の フローレートおよび交差点の飽和流量をともに 1 台/s とし, 車群の拡散はなく $(c=0)$ 遅れが 0 であるとい う条件下で交通量を最大にする特別のケースとして求め られることがわかった。

\section{5. むすび}

本研究は路線系統制御の遅れ最小化オフセットを求め た従来の DP モデルを改良し，遅れ最小化基準による オフセット最適化を行うとともに，その DP モデルを 用いて通過帯幅最大化基準によるオフセットの最適化を 行い, 通過带幅最大化オフセットは遅れ最小化オフセッ 卜に一定の条件を与えた場合の特別のケースとして求め ることができることを示した。

本研究を要約すると次のとおりである.

（1）本研究の DP モデルは路線系統制御を対象と し，交通流の 2 方向性と信号相互の影響を考慮した遅れ 最小化オフセットを求めるモデルである.

（2）本研究では従来の DP モデルに重要な改良を 加えたが，最も重要な改良点は交差点における車群変換 ルールを改良し，車群が赤信号にかからない場合を考慮
した点である。

（3）この改良により，DP の関数方程式は 2 次元か ら 4 次元になり，計算時間は長くなるが，通過帯幅最大 化オフセットを求めることができるようになる.

（４）さらに通過帯幅最大化オフセットを求める場合 においては車群変換が不連続になる点を改良した。

（5）DP 計算は道路条件（交差点間隔など），交通 条件 (交通量, 速度など), 信号条件 (周期，スプリット) を任意に与えて計算することができる.

（6）したがって上下両方向の交通量と速度が異な り，区間ごとにも速度が異なるほか，各信号のスプリッ 卜も異なるような一般的な条件で，遅れ最小化オフセッ トおよび通過帯幅最大化オフセットを求めることができ る.

DP モデルは手法的にはエレガントさはないが，柔軟 な手法であるから，今後の発展や応用が期待される.

今後の課題としては，境界条件すなわち両端交差点か らの流入車群の与え方などについて検討することが必要 である．また車群の変換ルールたとえば車群が 2 つに分 割される場合の処理方法の改善, 広がり係数の決定, 実 測やシミュレーションによる DP モデルの評価などに ついても検討していきたい.

なお，本研究の計算例は山口大学情報処理センター ACOS-850によって計算を行った。

\section{参 考 文 献}

1）越 正毅：交通信号の路線系統化について，道路， No. 291, pp. 354 365，1965 年 5 月.

2) Morgan, J. T. and Littlle, J. D. C. : Synchronizing traffic signals for maximal bandwidth, Operations Reserch, No. 6, pp. 896 911, 1964 年.

3）高田 弘・栗本 譲：系統信号方式による街路交通制御 に関する一考察，土木学会論文集，No. 124，pp.11～20, 1965 年 12 月.

4）枝村俊郎・久井 守・藤井登史雄：DPに上る系統信号 の最適化とシミュレーションによる検討，土木学会論文 報告集，第 209 号，pp. 115 122，1973 年 1 月.

5）奥谷 餀：街路網における信号機のオフセット最適化に 関する基礎的研究, 京都大学学位論文, pp. 70 90, 昭 和 47 年 7 月.

6）勅使河原可海：交通流の最適制御，日本機械学会論文集 (第 1 部), 35 巻, 275 号, 昭和 44 年 7 月.

7）奥谷 巌：動的計画法による街路網における交通信号才 フセットの最適化, 土木学会論文報告集, No. 221, pp. 59 71, 1974 年 1 月.

8）枝村俊郎・久井 守：系統式信号制御パラメーターに関 する一考察, 交通工学, 第 5 巻, 第 5 号, pp. $24 \sim 33$, 1970 年 9 月.

(1985.12.9・受付） 